\author{
Maria Sobieszczyk \\ ORCID: 0000-0002-0185-9795 \\ Katarzyna Wojciechowska \\ ORCID: 0000-0003-4249-8524
}

\title{
Zdolny czy zaburzony, typowy czy nietypowy, czyli jak pracować z dzieckiem w wieku przedszkolnym
}

Problematyka edukacji osób zdolnych zajmuje wielu pedagogów, psychologów od lat. Znaczące głosy w tych dyskusjach sygnalizują pilną potrzebę działań na rzecz uzdolnionych na wszystkich etapach kształcenia i wychowania. Chociaż wzrasta zainteresowanie jednostkami zdolnymi to istnieje szereg wyzwań do podjęcia. Wydaje się nam, że mamy do czynienia z niedostatkiem rozwiązań w tym zakresie. Przygotowanie nauczycieli edukacji przedszkolnej czy wczesnoszkolnej jest ciągle niewystarczające. Potrzebują oni wsparcia. Takiego wsparcia potrzebują także rodzice. Jedni i drudzy powinni umieć rozpoznawać uzdolnienia, możliwości dzieci, by budować pomost wzajemnej współpracy. Istnieją już inicjatywy w środowisku szkolnym i przedszkolnym dotyczące działań na rzecz funkcjonowania dziecka zdolnego, czego rezultatem jest obszerna oferta zajęć dla uczniów/dzieci zdolnych. Także w przestrzeni uniwersyteckiej prowadzone są już liczne badania funkcjonowania dziecka/ucznia zdolnego. Autorzy tych badań publikują ${ }^{1}$ swoje wyniki i upowszechniają je

1 Zob. np.: J. Uszyńska-Jarmoc, B. Kunat, M.J. Tarasiuk, Sukcesy uczniów zdolnych. Fakty-narracje-interpretacje, Centrum Kształcenia Ustawicznego w Białymstoku, Białystok 2014; B. Dyrda, Kompetencje nauczyciela w pracy z uczniami zdolnymiwybrane wyniki badań empirycznych nad edukacyjnym wspieraniem rozwoju uczniów zdolnych, „Chowanna” 2013, nr 41, s. 245-261; B. Surma, Praca z dzieckiem zdolnym w przedszkolu, „Edukacja Elementarna w Teorii i Praktyce” 2014, t. 32, nr 2, s. 11-22. 
na konferencjach naukowych, a co szczególnie istotne, także na konferencjach metodycznych i warsztatach dla szerokiego grona pedagogów, psychologów, terapeutów, nauczycieli edukacji wczesnoszkolnej i przedszkolnej oraz doradców zawodowych. Rozporządzenie Ministra Edukacji Narodowej z dnia 9 sierpnia 2017 r. w sprawie zasad organizacji i udzielania pomocy psychologiczno-pedagogicznej w publicznych przedszkolach, szkołach i placówkach ${ }^{2}$ wskazuje, by szczególną uwagę zwrócić na dzieci/uczniów zdolnych, jako odbiorców pomocy psychologiczno-pedagogicznej, to jednak nie określa jednak precyzyjnie metod i form pracy. W tym rozporządzeniu nauczyciel znajdzie jedynie informację, iż w przedszkolach pomoc psychologiczno-pedagogiczna ma opierać się na zajęciach rozwijających uzdolnienia ${ }^{3}$. Proces wspierania dzieci uzdolnionych ma polegać w przedszkolu przede wszystkim na obserwacji pedagogicznej i diagnozie gotowości szkolnej, współpracy z rodzicami oraz prowadzeniu zajęć rozwijających uzdolnienia. Zatem praca nauczyciela oscyluje głównie wokół rozwinięcia posiadanej zdolności. Niewiele jednak miejsca zajmuje kwestia specyficznego zachowania dzieci, ich rozwoju emocjonalnego. Wielu nauczycieli oraz rodziców ma kłopot w tej właśnie kwestii.

\section{Zagadnienie zdolności i twórczości}

W literaturze odnaleźć można szereg definicji zdolności, uzdolnień czy twórczości. Według B. Hornowskiego np. ,jest to indywidualna właściwość osobowości człowieka, której nie można sprowadzać do wykształconych nawyków. Można natomiast dzięki niej kształtować różnego rodzaju nawyki, sprawności i umiejętności"4. Z kolei W. Puślecki jako zdolności rozumie „predyspozycje psychiczne umożliwiające łatwą, sprawną oraz skuteczną realizację czegoś. Zdolności mogą być ponadto wszechstronne bądź ograniczać się do wybranej dziedziny”. Wiesława Limont uważa, że „problem zdolności można

\footnotetext{
http://dziennikustaw.gov.pl/du/2017/1591/1 (dostęp: grudzień 2019).

3 J. Kozielska, Niedyrektywne formy wspierania ucznia zdolnego, [w:] E. Piotrowski, M. Porzucek-Miśkiewicz (red.) Edukacja osób zdolnych, Wydawnictwo Naukowe UAM, Poznań 2019, s. 320-330.

4 B. Hornowski, Rozwój inteligencji i uzdolnień specjalnych, WSiP, Warszawa 1986, s. 48.

$5 \quad$ W. Puślecki, Wspieranie rozwoju dzieci w procesie wczesnej edukacji, Wydawnictwo Dolnośląskiej Szkoły Wyższej, Wrocław 2008, s. 34.
} 
rozpatrywać z różnych perspektyw, wyróżnia się bowiem różne rodzaje zdolności: ogólne, kierunkowe, twórcze"6. Zdolności człowieka przedstawić można zatem przez pryzmat rozmaitych definicji. Istotny z pewnością jest fakt, że każdy człowiek posiada zdolności. To od niego samego, ale także od środowiska, w jakim się wychowuje zależy to, $\mathrm{w}$ jakim stopniu je rozwinie, czy w ogóle to się stanie, co z tym zrobi w przyszłości.

Jeśli mówimy o uzdolnieniach jest to pewien układ zdolności, który gwarantuje ponadprzeciętny poziom wykonywania jakiegoś rodzaju działalności (literackiej, naukowej, plastycznej, technicznej, sportowej czy organizacyjnej). Zatem z pewnością stwierdzić można, że zdolności i uzdolnienia idą ze sobą w parze. Widzimy zatem, jak istotna jest rola osób dorosłych, opiekunów czy nauczycieli, specjalistów, którzy mają wpływ na wypatrzenie owej zdolności u dziecka oraz, co za tym idzie, jej rozwój. Zdolności mogą być także rozumiane jako potencjalna szansa, aktualnie niewystępująca, ale którą można nabyć. Może być to także biegłość, sprawność w wykonaniu jakiejś czynności. Zdolność przedstawia się także jako aktualną możliwość jednostki do wykonania jakiejś czynności czy indywidualną właściwość człowieka, zapewniającą mu powodzenie w jakimś działaniu.

Wszystkie wyżej przytoczone definicje zdolności i uzdolnień pokazują, że są to po prostu części osobowości człowieka, które z pewnością pomagają mu skutecznie się realizować i działać. Zwrócić uwagę należy na fakt, że niezwykle ważną rolę w rozwoju zdolności odgrywają dorośli.

Czym z kolei jest talent? Można powiedzieć, że jest to całość cech indywidualnych, które ujawniają się wcześnie, już w okresie dzieciństwa u małej grupy osób. Cechy te prowadzą do mistrzostwa w danej dziedzinie. Talent można również definiować jako wysoki poziom danej zdolności, która przejawia się w ponadprzeciętnej łatwości nabywania wiedzy lub sprawności w jakiejś dziedzinie np. talent muzyczny, aktorski, plastyczny. Każdy człowiek posiada jakieś zdolności. Każdy ma jakiś talent. Młody człowiek na początku rozwoju jest zdany na osoby dorosłe. To one mają w dużej mierze za zadanie wspomniane zdolności, talent dziecka dostrzec, a co za tym idzie w późniejszym czasie

6 W. Limont, Uczeń zdolny. Jak go rozpoznać i jak z nim pracować, GWP, Gdańsk 2010, s. 12. 
pomóc go rozwijać. Istotne jest motywowanie dziecka, wspomaganie go i wzmacnianie. Jeśli wszystkie te czynniki zostaną spełnione, z pewnością dziecko będzie rozwijało się w poczuciu, że zdolności posiada i wie jak z nich skorzystać.

\section{Przejawy zdolności u małych dzieci}

Szczególnie uzdolnieni i utalentowani często charakteryzują się wysokim ilorazem inteligencji, zmierzonym za pomocą różnych testów. Jednak zarówno rodzice jak i nauczyciele nie powinni przywiązywać do tego zbytniej wagi, dlatego, że istnieją, inne, wyróżniające takie dzieci, cechy.

Alicja Borowska do takich cech zalicza:

- wczesna umiejętność formułowania pełnych zdań i prowadzenia rozmowy z osobą dorosłą;

- szeroki zakres słownictwai wysoko rozwinięta zdolność czytania;

- niezaspokojona ciekawość i zamiłowanie do zadawania pytań;

- zdolność dłuższego utrzymywania koncentracji;

- skłonność do złożonych procesów myślowych;

- umiejętność abstrakcyjnego myślenia;

- skłonność do zabawy ze starszymi dziećmi;

- doskonała pamięć oraz umiejętność wykorzystywania przechowywanych informacji;

- zamiłowanie do zabaw językowych i gier słownych;

- zdolność łączenia abstrakcyjnych pojęć;

- niechęć do porażek, a czasem nieumiejętność zaakceptowania własnego braku racji;

- bogata wyobraźnia;

- brak cierpliwości do pracy na zajęciach;

- preferowanie pracy indywidualnej;

- zdolności przywódcze?.

Powinniśmy pamiętać, że nawet bardzo zdolne dziecko, to przede wszystkim dziecko i potrzebuje czasu oraz przestrzeni, aby rozwinąć się jako osoba. Dzieci muszą doskonalić się nie tylko intelektualnie, ale także społecznie i emocjonalnie i należy im dawać możliwość takiego

$7 \quad$ A. Borowska, Czy moje dziecko jest zdolne, Wydawnictwo Pedagogiczne ZNP, Kielce 2009, s. 60-65. 
rozwoju. Każde dziecko rodzi się z pewnymi cechami, które w trakcie rozwoju kształcą się i rozwijają. Nie każdy jednak ma taki sam potencjał. Ważne, aby w każdym dziecku odkryć zdolności i odpowiednio je rozwinąć. Niezwykle interesujący jest podział obszarów wyróżniony przez wspomnianą autorkę. Dzieci zdolne i utalentowane wyróżniają się zwykle w jakiejś określonej dziedzinie, dlatego mówimy o zdolnościach i talencie w określonym obszarze:

- intelektualnym - zdolność logicznego myślenia na wyższym poziomie abstrakcji;

- twórczym - zdolność oryginalnego myślenia i działania;

- naukowym - bycie dobrym w jednym lub kilku spokrewnionych dziedzinach;

- kierunkowym - zaangażowanie w zajęcia pozaszkolne, pozaobowiązkowe;

- społecznym - talent przywódczy - umiejętność nawiązywania kontaktów z innymi;

- fizycznym - wysoki poziom ruchowy, doskonała koordynacja, umiejętność współpracy z zespołem;

- artystycznym - przejawia się w zdolnościach plastycznych, muzycznych, aktorskich;

- mechanicznym - umiejętność rozkładania i składania urządzeń w celu zrozumienia ich działaniå.

Każde dziecko posiada określone cechy, według których możemy określić obszar uzdolnienia. Występuje wiele rodzajów talentów. W każdym z tych rodzajów wyróżnić możemy konkretne cechy. Dziecko, które prawdopodobnie przejawia zdolności w obszarze artystycznym lubi i często maluje, rysuje. Wybierając techniki pracy jest pomysłowe i sięga po te odległe. Interesuje się oglądaniem obrazków, wystaw artystycznych. Jeśli chodzi o talent twórczy to dziecko ma dużo pomysłów. Przejawia inwencję twórczą, chętnie wymyśla coraz to nowsze opowiadania, historyjki, zabawy. Jest ciekawe świata, zadaje mnóstwo pytań. Lubi eksperymentować, dochodzić do odpowiedzi na pytania w nietypowy sposób. Jeśli dziecko przejawia talent aktorski to nie ma problemu z występami na przedstawieniach. Często wybiera zabawy, gdzie można odgrywać różne role, zmieniać się. Posiada umiejętność sprawnego naśladowania. Interesuje się filmem. Lubi

$8 \quad$ Ibidem, s. 84-90. 
odwiedzać takie miejsca jak muzeum, kino, teatr. Cechy dziecka przejawiającego talent muzyczny są następujące: posiada doskonałe poczucie rytmu oraz słuch muzyczny. Przejawia chęć gry na wybranym instrumencie. W wolnych chwilach lubi słuchać muzyki. W związku z szeroko rozwiniętym słuchem muzycznym pięknie śpiewa. Dziecko przejawiające talent matematyczny jest zainteresowane liczbami. Sprawnie liczy w pamięci. Przejawia zainteresowania grami matematycznymi. Jest także wytrwałe w działaniu oraz niezwykle aktywne na zajęciach matematycznych. Mówiąc o dziecku przejawiającym talent przywódczy mówimy, że posiada umiejętność manipulowania innymi. Ma potrzebę doszukiwania się sprawiedliwości społecznej. Musi być w centrum zainteresowania. W czasie zabawy lubi kontrolować jej przebieg, nie posiada także problemów w kwestii przystosowania się do nowych sytuacji. Talent sportowy dziecka, zauważyć można poprzez to, że ma mnóstwo energii. Na co dzień potrzebuje dużo ruchu. Na zajęciach sportowych szybko przyswaja sobie reguły gry oraz chętnie uczestniczy w zajęciach ruchowych. Wie co to rywalizacja i ją lubi. Talent pisarski u dziecka zauważymy, kiedy często czyta bądź ogląda książki. Czerpie przyjemność z czytania. Dzieci te szybciej niż rówieśnicy opanowują umiejętność czytania i pisania. Posiada bogatą wyobraźnię, potrafi wymyślać historyjki na poczekaniu. Talent naukowy u dziecka zauważymy poprzez jego język wypowiedzi. Potrafi ono wyrażać się zrozumiale i precyzyjnie. Jego sposób porozumiewania się jest niezwykle rozwinięty. Potrafi skupić uwagę na dłuższy czas, kiedy zajmuje się tym, co go interesuje. Dziecko przejawiające talent techniczny to takie, które interesuje się urządzeniami mechanicznymi, ich budową i funkcjami. Świetnie odnajduje się w zabawach konstrukcyjnych. Posiada łatwość rozumienia łamigłówek oraz umiejętność wyłapywania podchwytliwych pytań ${ }^{9}$.

Wiele przedstawionych powyżej cech posiadanych w związku z konkretnym talentem z pewnością ułatwia obserwacje dziecka w celu zdiagnozowania. Należy zwrócić uwagę na fakt, że dziecko może posiadać kilka talentów, jednak nie wszystkie rozwinięte na tym samym poziomie. W przypadku dzieci uzdolnionych rodzaj talentu, zdolności jest często skoncentrowany wokół jednej dziedziny. Należy w takim przypadku dzieci wspierać, pokazując im kierunki rozwoju swojego

$\overline{9} \quad$ Ibidem, s. 34-39. 
talentu, wskazać profity, jakie może mieć w przyszłości. Rola nauczyciela w przedszkolu, czy szkole polega na dostosowaniu wymagań dla dziecka zdolnego tak, by nie stało w miejscu, a ciągle się rozwijało.

\section{Trudności emocjonalno-społeczne dziecka zdolnego}

Istnieje pogląd, że dzieci/uczniowie zdolni to indywidualiści. W wielu źródłach istnieje wyraźne wskazanie na cechy ich „inności”. Są one u nich widoczne w formie intelektu, zachowania i emocji. Dzieci te charakteryzują się posiadaniem niesamowitej chłonności umysłu, są sprawni w myśleniu. Dzieci zdolne niezwykle szybko kojarzą potrzebne wiadomości w celu wykorzystania do innowacyjnych działań. Nie boją się nowych wyzwań i dobrze odnajdują się w nowych sytuacjach. Mają bogaty zasób wiadomości, szybsze tempo myślenia. Często zadają mnóstwo różnorodnych pytań, pytają o uzasadnienie, wypowiadają swoje uwagi, są dociekliwi i ciekawi. Powyższe zachowania traktowane są jako „mądrzenie się” i przeszkadzanie w prowadzeniu zajęć, a także jako objaw złego wychowania. Jednak uczniowie ci, pomimo upominania i często niezbyt miłych skutków takiego zachowania, upierają się przy swoich racjach. Istotne jest, aby pamiętać, że nie robią tego, bo są złośliwe lub chcą sprawić komuś przykrość, tylko dlatego, że chcą pozyskać informacje. Dzieci zdolne są nazywane dziećmi „trudnymi”. Jest to związane $\mathrm{z}$ występowaniem $\mathrm{u}$ nich tzw. nadpobudliwości emocjonalnej, ruchowej i psychomotorycznej. Nadpobudliwość emocjonalna przejawia się nadmierną reakcją emocjonalną. Uczniowie zdolni mają więcej niezaspokojonych potrzeb emocjonalnych niż ich rówieśnicy. Ich wysoka sprawność intelektualna sprawia, że są oni traktowani przez osoby dorosłe zbyt poważnie, a co za tym idzie cierpi na tym ich sfera emocjonalna. Występuje u nich także większa niż u innych dzieci rozbieżność pomiędzy sferą rozwoju poznawczego a emocjonalnego ${ }^{10}$.

Nadpobudliwość psychomotoryczna, charakteryzująca dziecko zdolne określana jest jako dekoncentracja uwagi i brak skupienia, co jest związane $\mathrm{z}$ częstym zamyślaniem się lub prowadzeniem rozmów z kolegami. Uczniowie zdolni charakteryzują się dużą podzielnością uwagi, dlatego często w myślach mogą drążyć ciekawe aspekty poruszanych zagadnień, błyskawicznie rozwiązywać nowe zadania,

$\overline{10}$ B. Hornowski, Rozwój inteligencji..., s. 62-95. 
zredagować opowiadanie czy też spontanicznie ułożyć wiersz. Ich umysły pracują intensywnie, ale nie zawsze jest to dostrzegalne na zewnątrz np. w postaci mowy ciała.

Dziecko zdolne często ma też trudności w kontaktach $\mathrm{z}$ otoczeniem, ma problem we współpracy, popada w konflikty, a niekiedy woli przebywać samo ze sobą. W dużej mierze jest to spowodowane tym, że często są one zbyt pewne siebie, uważają, że inni nie dorównują im pod względem wiedzy i posiadanych umiejętności, są cyniczne, krytyczne oraz nietolerancyjne w stosunku do błędów popełnionych przez innych.

W kontaktach między dzieckiem wybitnie zdolnym i otoczeniem konieczna jest obopólna tolerancja. Ono powinno starać się rozumieć tych, którzy nie dorównują mu w pewnych dziedzinach, ale też jego zachowania i reakcje często nietypowe i odmienne od powszechnie przyjętych muszą być tolerowane przez ludzi, wśród których żyje.

\section{Cechy osobowości oraz potrzeby dzieci zdolnych}

Podczas badań na jednostkami I. Czaja-Chudoba stwierdziła, że dzieci zdolne w porównaniu z ich przeciętnie zdolnymi rówieśnikami, cechują się głębszymi i rozleglejszymi dążeniami poznawczymi, większą oryginalnością myślenia, wyższym poziomem wiary we własne siły i zaufania do samego siebie, silnym dążeniem do osiągnięć na polu intelektualnym oraz specyficznym poczuciem humoru. Każdemu człowiekowi żyjącemu w społeczeństwie niezbędne do prawidłowego funkcjonowania jest zaspokojenie wszystkich potrzeb. Mówimy tu o potrzebach fizjologicznych, społecznych, emocjonalnych i poznawczych. Także dziecko ma określone potrzeby i aby ono prawidłowo funkcjonowało należy je zaspokoić. Jest to niezwykle ważne także do wykorzystywania możliwości dziecka. Istotne jest zachowanie równowagi. Dzieci, które mają rozwinięte potrzeby poznawcze są ciekawe, głodne wiedzy na różne tematy, w sposób aktywny poszukują możliwości wzbogacania wiedzy i umiejętności. Używają do tego analizowania, samodzielnego działania, eksperymentowania ${ }^{11}$.

Warto wspomnieć o roli nauczycieli i rodziców, o których pisze autorka, którzy powinni organizować dzieciom zabawy i zajęcia będące

11 I. Czaja-Chudyba, Jak rozwijać zdolności dziecka, WSiP, Warszawa 2009, s. 55-78. 
bodźcem do pobudzenia ich naturalnej ciekawości świata. Powinni także dawać im możliwość samodzielnego poznawania świata. Pomoże w tym:

- stwarzanie sytuacji do twórczego i samodzielnego rozwiązywania;

- dostosowywanie tempa pracy i przekazywania wiedzy do możliwości dziecka;

- motywowanie do samodzielnej pracy;

- zachęcanie dzieci i rodziców do korzystania z różnego rodzaju zajęć pozalekcyjnych ${ }^{12}$.

Wszystkie wyżej opisane rozważania dotyczące kierunków badań w zakresie zdolności i uzdolnień pokazują, że pojawia się coraz większe zainteresowanie tą tematyką. Badania te ujawniają jakoby dominujące znaczenie w rozwijaniu zdolności i uzdolnień od najmłodszych lat ma szkoła, przedszkole, środowisko rodzinne. Dzięki temu, że rzeczywistość podlega ciągłym zmianom i rozwojowi, motywuje to władze państwowe do wzbogacania informacji na temat dzieci zdolnych w celu wdrażania nowych rozwiązań wsparcia. Skutkiem mogłoby być aktywniejsze włączanie nauczycieli $\mathrm{w}$ doskonalenie systemu pracy z dzieckiem zdolnym. W końcu to oni są osobami, które spędzają z dziećmi bardzo dużo czasu. Są ich mentorami, partnerami w sytuacjach edukacyjnych. Powinni pobudzać dzieci, ukierunkowywać w odpowiednią stronę, zachęcać do dalszego rozwoju.

Podstawą diagnozy dziecka zdolnego jest przyjęcie określonej definicji i koncepcji zdolności. Najczęściej przyjmuje się koncepcję zdolności ogólnej, która podkreśla, że osoba zdolna charakteryzuje się wysokim ilorazem inteligencji, twórczą postawą i silną motywacją do uczenia się. Najbardziej znaną i stosowaną przez pedagogów jest koncepcja inteligencji wielorakich Howarda Gardnera. Zarówno teoretyczne założenia tej koncepcji, jak i diagnostyczne narzędzia pomagają w planowaniu zajęć ukierunkowanych na różne aktywności. Świadomość zróżnicowania rozwoju dzieci i ich możliwości nadaje nowy wymiar rozumienia celu edukacji, jakim jest wszechstronny rozwój dzieci.

$\overline{12}$ Ibidem, s. 151-163. 


\section{Zamiast zakończenia, kilka rad, jak pracować z dzieckiem zdolnym i go nie zniechęcić}

Wydawać by się mogło, że słysząc słowa „zdolne dziecko” wyobrażamy sobie grzeczne, bawiące się lub pilnie uczące się dziecko. Rzeczywistość bywa jednak często inna, gdyż zdolne dziecko czy uczeń nie musi wcale być przysłowiowym prymusem. Te dzieci często sprawiają kłopoty wychowawcze i mogą wymagać od nas różnego wsparcia, które umożliwi im skoncentrowanie się na rozwijaniu ich talentów. Jeśli tej pomocy nie otrzymają lub metody okażą się nieadekwatne do potrzeb, dziecko może się zniechęcić, a w przypadku ucznia stracić zainteresowanie nauką. Oto kilka wskazówek dla nauczycieli:

- wspieraj i rozbudzaj zainteresowania;

- pozwalaj pytać i komentować;

- dobieraj metody i poziom nauczania;

- okazuj wsparcie i szacunek;

- powiedz NIE stereotypom;

- integruj;

- mądrze motywuj;

- zarażaj pasją;

- dawaj przestrzeń;

- współpracuj z rodzicami i edukuj ich.

Podsumowując, praca z dzieckiem zdolnym w przedszkolu powinna polegać przede wszystkim na rozpoznawaniu jego zainteresowań, potrzeb i możliwości. Trzeba przyjąć, że każde dziecko posiada jakieś zdolności, trzeba je tylko dostrzec i wspierać. Dlatego praca nauczyciela przedszkola powinna polegać na holistycznym podejściu do pracy z dzieckiem oraz dbaniu o jego wszechstronny rozwój, gdyż wiek przedszkolny jest okresem, w którym można niwelować braki rozwojowe i oddziaływać całościowo na rozwój dziecka. Nauczyciel przedszkola musi pamiętać, że w jego grupie mogą znaleźć się tzw. dzieci „podwójnie wyjątkowe” czyli takie, które przejawiają wybitne zdolności, a z drugiej strony charakteryzują się pewnymi deficytami rozwojowymi i wymagają specjalistycznego wsparcia. Większość programów edukacji przedszkolnej wskazuje dość dobrze jak wspierać potencjał twórczy dzieci. Ponadto w wielu placówkach organizuje się dodatkowe zajęcia pozwalające rozwijać zdolności specjalne. Są to zajęcia o charakterze artystycznym, plastycznym, zajęcia matematyczne, czy 
szachowe. W przedszkolach w celu harmonijnego, wszechstronnego rozwoju wszystkich wychowanków stosuje się m.in. metodę kinezjologii edukacyjnej P. Dennisona, czyli specjalne ćwiczenia fizyczne, które aktywizują obie półkule mózgowe. Korzystając z tych ćwiczeń dzieci mogą liczyć na polepszenie się ich koncentracji uwagi, koordynacji wzrokowo-ruchowej. Rozwija się także zmysł wzroku i słuchu oraz równowagi. Wykorzystuje się także różne naturalne metody nauki czytania takie jak: metoda I. Majchrzak, G. Domana czy metodę Dobrego Startu M. Bogdanowicz. Bardzo korzystnie też wpływa na dzieci gimnastyka twórcza R. Labana, w której istotna jest naturalna ruchliwość dziecka. Ciekawym rozwiązaniem w zakresie realizacji postulatów pracy z dzieckiem w wieku przedszkolnym w tym także typowym czy nietypowym, zdolnym czy zaburzonym wydaje się być system pedagogiczny M. Montesorii. Koncepcja ta pozwala na indywidualny rozwój każdego dziecka. Obecnie w wielu placówkach przyjmuje się i słusznie wspomnianą wyżej koncepcję inteligencji wielorakich, która podkreśla, że osoba zdolna charakteryzuje się wysokim ilorazem inteligencji, twórczą postawą i silną motywacją do uczenia się. Kończąc nasze przemyślenia dotyczące pracy nauczyciela edukacji przedszkolnej z dziećmi chcemy posłużyć się myślą D. Lewisa,

dziecko rodzi się wszechstronnie uzdolnione, z pełną możliwością rozwoju we wszystkich kierunkach, potencjalną, wybitną inteligencją, zadatkami na rozwijanie wielkiej twórczości oraz dużym talentem społecznym. Trzeba stworzyć mu możliwości do optymalnego rozwoju ${ }^{13}$.

Rodzice, nauczyciele, wychowawcy powinni zadbać o to, by tego potencjału dzieci nie zmarnować.

\begin{abstract}
The article raises the problem, increasingly discussed by pedagogues, of the functioning of a child with special educational needs in a preschool environment. The article focuses primarily on the situation of a talented, unusual child often treated as the difficult one. Many tips, methodological advices and solutions addressed to educators of unusual children were introduced, in order to provide support for teachers and parents in recognizing talents and dealing with such children.
\end{abstract}

13 D. Lewis, Jak wychować zdolne dziecko, Państwowy Zakład Wydawnictw Lekarskich, Warszawa 1988, s. 9. 


\section{Bibliografia}

Borowska A., Czy moje dziecko jest zdolne, Wydawnictwo Pedagogiczne ZNP, Kielce 2009.

Czaja-Chudyba I., Jak rozwijać zdolności dziecka, WSiP, Warszawa 2009.

Dyrda B., Kompetencje nauczyciela w pracy z uczniami zdolnymi - wybrane wyniki badań empirycznych nad edukacyjnym wspieraniem rozwoju uczniów zdolnych, „Chowanna” 2013, nr 41.

Hornowski B., Rozwój inteligencji i uzdolnień specjalnych, WSiP, Warszawa 1986.

Kozielska J., Niedyrektywne formy wspierania ucznia zdolnego, [w:] E. Piotrowski, M. Porzucek-Miśkiewicz (red.) Edukacja osób zdolnych, Wydawnictwo Naukowe UAM, Poznań 2019.

Lewis D., Jak wychować zdolne dziecko, Państwowy Zakład Wydawnictw Lekarskich, Warszawa 1988.

Limont W., Uczeń zdolny. Jak go rozpoznać i jak z nim pracować, GWP, Gdańsk 2010.

Puślecki W., Wspieranie rozwoju dzieci w procesie wczesnej edukacji, Wydawnictwo Dolnośląskiej Szkoły Wyższej, Wrocław 2008.

Surma B., Praca z dzieckiem zdolnym w przedszkolu, „Edukacja Elementarna w Teorii i Praktyce" 2014, t. 32, nr 2.

Uszyńska-Jarmoc J., Kunat B., Tarasiuk M.J., Sukcesy uczniów zdolnych. Fakty-narracje-interpretacje, Centrum Kształcenia Ustawicznego w Białymstoku, Białystok 2014.

\section{Netografia}

http://dziennikustaw.gov.pl/du/2017/1591/1 (dostęp: grudzień 2019). 